\title{
Professional Communication Strategies in the Design Process of an Open Education Tutor
}

Zolotykhin Sergey Alexandrovich ${ }^{1}$ Mashkina Natalya Pavlovna ${ }^{2}$ Sinkevich Konstantin Mikhailovich ${ }^{3}$ Laktionov Viktor Viktorovich ${ }^{4}$

\section{Journal for Educators, Teachers and Trainers, Vol. 12 (1)}

\author{
https://jett.labosfor.com/
}

Date of reception: 15 March 2020

Date of revision: 12 June 2020

Date of acceptance: 18 August 2020

Zolotykhin Sergey Alexandrovich, Mashkina Natalya Pavlovna, Sinkevich Konstantin Mikhailovich, Laktionov Viktor Viktorovich(2021). Professional Communication Strategies in the Design Process of an Open Education Tutor. Journal for Educators, Teachers and Trainers, Vol. 12(1). 48 - 56.

\footnotetext{
${ }^{1}$ Kursk State University, Radishchev Street, 33, Kursk, Russian Federation, Department of Pedagogy and Professional Education, Associate Professor, PhD in pedagogy.

${ }^{2}$ Southwest State University, 50 Let Oktyabrya, 94, Kursk, Russian Federation, Department of fundamental and applied linguistics, Lecturer.

${ }^{3}$ Kursk State University, Radishchev Street, 33, Kursk, Russian Federation, Department of theory of foreign languages and professional communication, Associate Professor, $\mathrm{PhD}$ in pedagogy.

${ }^{4}$ State Budgetary Educational Institution of Further Education of the city of Sevastopol "Sevastopol Station for Young Technicians”, 39, Gorpishchenko Street, Sevastopol, Deputy Director for Project Management.
} 


\title{
Journal for Educators, Teachers and Trainers, Vol. 12 (1) \\ ISSN 1989 - 9572 \\ https://jett.labosfor.com/
}

\section{Professional Communication Strategies in the Design Process of an Open Education Tutor}

Zolotykhin Sergey Alexandrovich ${ }^{1}$, Mashkina Natalya Pavlovna ${ }^{2 *}$, Sinkevich Konstantin Mikhailovich ${ }^{3}$ Laktionov Viktor Viktorovich ${ }^{4}$

${ }^{1}$ Kursk State University, Radishchev Street, 33, Kursk, Russian Federation, Department of Pedagogy and Professional Education, Associate Professor, $\mathrm{PhD}$ in pedagogy.

${ }^{2}$ Southwest State University, 50 Let Oktyabrya, 94, Kursk, Russian Federation, Department of fundamental and applied linguistics, Lecturer.

${ }^{3}$ Kursk State University, Radishchev Street, 33, Kursk, Russian Federation, Department of theory of foreign languages and professional communication, Associate Professor, $\mathrm{PhD}$ in pedagogy.

${ }^{4}$ State Budgetary Educational Institution of Further Education of the city of Sevastopol "Sevastopol Station for Young Technicians", 39, Gorpishchenko Street, Sevastopol, Deputy Director for Project Management.

*Corresponding Author

Email ID: mashkinanatasha@mail.ru,_moodlefree@yandex.ru, laktionov-victor@bk.ru, prof_communication@mail.ru

\begin{abstract}
The article describes the professional communication strategies in the design activities of an open education tutor and the process of mastering these strategies. This process is based on the close relationship between the tutor's professional-oriented goals and his/her design levels in open education. Communication strategies allow the tutor to implement successfully professional activities in open education. Nowadays the problem of tutors' mastering the professional communication strategies is very relevant due to the increasing opportunities of open education.

The article presents the progress and results of the experimental work on the testing of the effectiveness of the proposed model of mastering the professional communication strategies by open education tutors. This model is aimed at developing communication skills in the process of their professional activity. In particular, the model is thought to achieve the necessary level of motivation for mastering the professional communication strategies in open education.

The article presents the results of experimental work processed by methods of mathematical statistics. The results presented in the paper confirm the proposed provisions.
\end{abstract}

Keywords: tutor, professional communication strategies, open education, motivation, design activities.

\section{INTRODUCTION}

Today the demand for tutoring in Russia is rising due to the fact that the tutor is one of the most needed future professions directly related to communication. The Atlas of New Professions includes the profession of a tutor as well as a developer of educational trajectories, an organizer of design training, a mentor for startups in the category of professions uniting education and communication [Atlas novyh professij].

Tutoring is currently determined by two important trends in education. The first of them is related to the personalization of the educational process. However it is relevant to mention that there is a fundamental difference between the principle of individualization and the one of personalization. Individualization is aimed at removing obstacles and achieving externally set goals, usually defined in the Federal Educational Standard. Personalization recognizes the students' right to form their own learning goals and strategies to achieve them. This definition leads to the next important trend in modern education, which is the formation of an open 
educational environment. Therefore, personalization is generally considered as the process of setting personal learning goals and choosing an individual strategy for achieving these goals. Thus, personalization is possible only in the situation of going beyond formal education, represented by the educational environment of a school, University, etc. In fact, there are formal, none-formal and informal types of education in an open educational environment.

The analysis of some theoretical researches has shown that there is an interest in problems related to:

- the tutor's design activity:

- in the field of open education: L.V. Bendova, L.A. Kosolapova;

- in the field of informal education: O.V. Pavlova, D. Cofer;

- the formation of professional communication strategies:

- in the field of methodology: E.I. Passov, G.A. Kitaygorodskaya, V.V. Safonova;

- in the field of psychology: A.A. Leontiev, I.A. Zimnyaya, L.S. Vygotsky;

- in the field of pedagogy: A.V. Mudrik, V.A. Slastenin.

During the process of individual goals implementation a personal learning environment is formed. This environment represents a personal construct when every student decomposes the educational content of any educational environment and re-structures this content into a personal system of knowledge and competencies. One of the tutor's functions is formation of a personal educational space. The more skills the tutor possesses, the more successful the personal educational space will be.

\section{MATERIALS AND METHODS}

There are researches that analyze different tutoring activities. One of them is V. V. Maksimov's research on the experience of including tutoring activities in different historical contexts of University education. For instance, the tutor performed a mentoring function in relation to less experienced students, focusing his activities on a certain type of spiritual practice in medieval universities. Next step was the tutor's transformation into an assistant with his functions narrowed to local-methodical ones in the universities of the Renaissance that were focused on the scientific rather than the theological picture of the world. Finally, today's new type of universities, defined as design and research ones, highlight the ability to work with a manageable future as the main value of education. So, the tutor activity becomes popular again: "the tutor begins to act as a developer of educational projects or programs or as a consultant in the field of educational services", combining the positions of a mentor, assistant and designer [Maksimov 2000: 60].

Thus the main functions of the tutor in relation to students can be identified as following:

- $\quad$ diagnosing the state and progress of the training;

- $\quad$ goal setting and designing of training modules and specific training sessions;

- motivating and involving the students in the processes of self-education and self-development;

- $\quad$ managing students' activities;

- $\quad$ correcting students' mistakes;

- controlling over the execution of tasks;

- $\quad$ reflecting on their and own activities.

Undoubtedly, the effectiveness of these functions depend on the tutor's personal skills including professional communication. In line with the research on the verification of the effectiveness of the process of obtaining the professional communication strategies by future Masters of Education the following three criteria were chosen to determine the effectiveness of the formation of the professional communication strategies for the open education tutors (Table 1).

Table 1: Criteria and indicators of formation of the professional communication strategies for the open education tutors

\begin{tabular}{|l|l|l|}
\hline Criteria & Indicators & Diagnostic methods \\
\hline $\begin{array}{l}\text { the motivational-value } \\
\text { criterion }\end{array}$ & $\begin{array}{l}\text { 1) necessary level of motivation for mastering professional } \\
\text { communication strategies }\end{array}$ & questionnaires \\
\cline { 2 - 3 } & 2) system of values & M. Rokich's Method \\
\hline $\begin{array}{l}\text { the personal } \\
\text { development criterion }\end{array}$ & $\begin{array}{l}\text { 3) the ability to apply strategies to determine the direction of } \\
\text { the individual trajectory of personal development }\end{array}$ & $\begin{array}{l}\text { studying of success } \\
\text { stories }\end{array}$ \\
\hline
\end{tabular}




\begin{tabular}{|l|l|l|}
\hline & $\begin{array}{l}\text { 4) the ability to adopt strategies for implementing the } \\
\text { individual trajectory of personal development }\end{array}$ & \\
\hline the reflexive criterion & $\begin{array}{l}\text { 5) the ability to analyze the effectiveness of the professional } \\
\text { communication strategies in their own activities }\end{array}$ & video analysis \\
\cline { 2 - 4 } & $\begin{array}{l}\text { 6) the ability to analyze the effectiveness of the professional } \\
\text { communication strategies in the activities of colleagues }\end{array}$ & $\begin{array}{l}\text { creating a personal } \\
\text { road map }\end{array}$ \\
\hline
\end{tabular}

The pedagogical experiment was aimed at improving the effectiveness of the process of mastering professional communication strategies in the design activity of the open education tutors. Therefore, 28 future Masters of Education, who are currently taking part in different tutoring courses participated in the experiment.

\section{FINDINGS}

In the materials of the Open University of Great Britain, the main roles of a tutor are highlighted and the model of a "comprehensive tutor" is presented [Atayan 2201: 114]. The structural composition of the tutor model is represented through the roles and positions in which these roles can be manifested. The model is based on two approaches: the "tutor orientation" approach and the "student orientation" approach. Each approach is represented by a different role.

The role "tutor as arbiter" focuses on the tutor explaining the course content. The ideas and knowledge are passed from the tutor to the students. This transfer of knowledge is a part of the tutor's job. The second position of this role is to check whether students understand the course ideas correctly. The tutor creates a certain formation, the required image, for students. These two positions are integral parts of the tutor's role as an arbiter [Kovaleva 2014: 63-71].

The role "tutor as an equal" emphasizes the intellectual autonomy of the students. The first manifestation of this role is the position of the tutor as a guide, who leads his students to understanding. Another component of the tutor's role as an equal is the tutor's position as a person who stimulates the development of a personal approach to working with the ideas of the course. This position of the tutor as a teacher is characterized by his desire to provide a deeper understanding of the ideas discussed by relying on the students' statements and structuring their generated content. These two positions, the tutor as a guide and the tutor as an educator show that the tutor supports the desire of his students to express their own opinions and judgments [Kovaleva 2014: 63-71].

The tutor's choice of the role depends on such personal characteristics as his system of values, motivation, abilities to analyze and adopt strategies of professional communication [Kovaleva 2013: 51-56].The experimental part of this research was aimed at identifying the level of motivation for mastering the strategies. The method of M. Rokich was used to determine the most significant value orientations of open education tutors [Rokich 1973: 20-28].

The experimental data was processed by statistical methods based on the use of the criterion (Chi-square). This $\chi^{2}$ criterion is applied "to compare the distribution of objects of two aggregates by the state of a certain property based on the measurements of this property in two independent samples from the calculated aggregates" [Grabar, Krasnianskaya 1977: 96].

The reliability of the obtained conclusions based on the application of the $\chi^{2}$ criterion is ensured by compliance with a number of necessary requirements [Grabar, Krasnianskaya 1977: 96-97]:

1) random determination of the composition of the studied samples:

- 12 open education tutors in the control sample;

- 16 open education tutors in the experimental sample);

2) the independence of the samples;

3) to use of a simple scale with three levels: low, medium, and high.

The distribution of the open education tutors by levels of formation of the indicators of motivational and value criterion in each group at the ascertaining stage of the experiment is presented in the Table 2.

Table 2: The distribution of the open education tutors of the control and experimental groups by the motivational-value criterion

\begin{tabular}{|l|l|l|l} 
The indicators & $\begin{array}{l}\text { The control group } \\
(\text { people. / \% })\end{array}$ & $\begin{array}{l}\text { The experimntel group } \\
\text { (people. / \%) }\end{array}$ & $\begin{array}{l}\text { Chi- } \\
\text { square }\end{array}$
\end{tabular}




\begin{tabular}{|l|l|l|l|l|l|l|l|}
\hline & Low & Medium & High & Low & Medium & High & \\
\cline { 1 - 9 } $\begin{array}{l}\text { 1. The motivation to mastering the } \\
\text { professional communication strategies }\end{array}$ & 6 & 4 & 2 & 8 & 5 & 3 & \multirow{2}{*}{0,26} \\
\cline { 2 - 10 } & $50 \%$ & $33 \%$ & $17 \%$ & $50 \%$ & $31 \%$ & $19 \%$ & \\
\hline \multirow{2}{*}{ 2. Value system } & 4 & 5 & 3 & 8 & 4 & 4 & \multirow{2}{*}{0,28} \\
\cline { 2 - 8 } & $33 \%$ & $42 \%$ & $25 \%$ & $50 \%$ & $25 \%$ & $25 \%$ & \\
\hline
\end{tabular}

To calculate the empirical value of the $\chi^{2}$ criterion the following formula was used [Novikov 2004: 52]:

$$
\chi_{\mathrm{emp}}^{2}=N * M * \sum_{i=1}^{L} \frac{\left(\frac{n_{i}}{N}-\frac{m_{i}}{M}\right)^{2}}{n_{i}+m_{i}} .
$$

In the formula 1 the value of $\mathrm{N}$ stands for the number of the future masters of Education, members of the experimental group and equals to $16(\mathrm{~N}=16), \mathrm{M}$ is the number of the open education tutors, members of the control group and equals to $12(\mathrm{M}=12), \mathrm{L}$ is the number of development levels ( $\mathrm{L}=3$ : low, medium, high), $n_{i}$ is the number of the members of the experimental group that received $\mathrm{i}$-a level $(\mathrm{n} 1=6, \mathrm{n} 2=4, \mathrm{n} 3=2), m_{i}$ is the number of the members of the control group that received i-level $(\mathrm{m} 1=8, \mathrm{~m} 2=5, \mathrm{~m} 3=3)$. Therefore, using formula 1, we get:

$$
\chi_{\text {emp }}^{2}=12 * 16 *\left(\frac{\left(\frac{6}{12}-\frac{8}{16}\right)^{2}}{6+8}+\frac{\left(\frac{4}{12}-\frac{5}{16}\right)^{2}}{4+5}+\frac{\left(\frac{2}{12}-\frac{3}{16}\right)^{2}}{2+3}\right)=0,26
$$

The critical value of this criterion for the significance level of 0.05 with three gradations is 5.99 [Bolshev, Smirnov 1983]. The empirical value of this criterion is less than the critical value for the studied indicator:

$$
\chi_{\text {emp }}^{2}<\chi_{0,05}^{2}(0,26<5,99) \text {. }
$$

Thus, we are allowed to accept the null hypothesis, that states that the levels of the indicator "The motivation to mastering the professional communication strategies" for the students of the control and experimental samples at the ascertaining stage are equal. From this perspective the alternative hypothesis claims that the levels of the indicator "The motivation to mastering the professional communication strategies" for students of the control and experimental samples at the ascertaining stage are not equal.

In the formula 4 the value of $\mathrm{N}$ stands for the number of the open education tutors, members of the experimental group and equals to $12(\mathrm{~N}=12), \mathrm{M}$ is the number of the future masters of Education, members of the control group and equals to $16(\mathrm{M}=16), \mathrm{L}$ is the number of development levels $\left(\mathrm{L}=3\right.$ : low, medium, high), $n_{i}$ is the number of the members of the experimental group that received $\mathrm{i}$-a level $(\mathrm{n} 1=4, \mathrm{n} 2=5, \mathrm{n} 3=3), m_{i}$ is the number of the members of the control group that received i-level $(\mathrm{m} 1=8, \mathrm{~m} 2=4, \mathrm{~m} 3=4)$. Therefore, using formula 1, we get:

$$
\chi_{\text {emp }}^{2}=12 * 16 *\left(\frac{\left(\frac{4}{12}-\frac{8}{16}\right)^{2}}{4+8}+\frac{\left(\frac{5}{12}-\frac{4}{16}\right)^{2}}{5+4}+\frac{\left(\frac{3}{12}-\frac{4}{16}\right)^{2}}{3+4}\right)=0,28
$$

The open education tutors were also asked to evaluate their abilities to apply and adopt strategies to determine the direction of the individual trajectory of personal development and the abilities to analyze the effectiveness of the professional communication strategies in their own activities and in the activities of their colleagues. The results are shown in the Tables 3 and 4 . 
Table 3: The distribution of the open education tutors of the control and experimental groups at the ascertaining stage by the personal development criterion

\begin{tabular}{|c|c|c|c|c|c|c|c|}
\hline \multirow[t]{2}{*}{ The indicators } & \multicolumn{3}{|c|}{$\begin{array}{l}\text { The control group } \\
\text { (people. /\%) }\end{array}$} & \multicolumn{3}{|c|}{$\begin{array}{l}\text { The experimntel group } \\
\text { (people. /\%) }\end{array}$} & \multirow[t]{2}{*}{$\begin{array}{l}\text { Chi- } \\
\text { square }\end{array}$} \\
\hline & Low & Medium & High & Low & Medium & High & \\
\hline \multirow{2}{*}{$\begin{array}{l}\text { 1. The ability to apply strategies to determine the } \\
\text { direction of the individual trajectory of personal } \\
\text { development }\end{array}$} & 7 & 4 & 1 & 9 & 5 & 2 & \multirow[t]{2}{*}{0,13} \\
\hline & $59 \%$ & $33 \%$ & $8 \%$ & $56 \%$ & $31 \%$ & $13 \%$ & \\
\hline \multirow{2}{*}{$\begin{array}{l}\text { 2. The ability to adopt strategies for implementing } \\
\text { the individual trajectory of personal development }\end{array}$} & 6 & 4 & 2 & 8 & 4 & 4 & \multirow[t]{2}{*}{0,38} \\
\hline & $50 \%$ & $33 \%$ & $17 \%$ & $50 \%$ & $25 \%$ & $25 \%$ & \\
\hline
\end{tabular}

Table 4: The distribution of the open education tutors of the control and experimental groups at the ascertaining stage by the reflexive criterion

\begin{tabular}{|c|c|c|c|c|c|c|c|}
\hline \multirow[t]{2}{*}{ The indicators } & \multicolumn{3}{|c|}{$\begin{array}{l}\text { The control group } \\
\text { (people. /\%) }\end{array}$} & \multicolumn{3}{|c|}{$\begin{array}{l}\text { The experimntel group } \\
\text { (people. /\%) }\end{array}$} & \multirow[t]{2}{*}{$\begin{array}{l}\text { Chi- } \\
\text { square }\end{array}$} \\
\hline & Low & Medium & High & Low & Medium & High & \\
\hline \multirow{2}{*}{$\begin{array}{l}\text { 1. The ability to analyze the effectiveness of the } \\
\text { professional communication strategies in their own } \\
\text { activities }\end{array}$} & 6 & 4 & 2 & 8 & 5 & 3 & \multirow[t]{2}{*}{0,26} \\
\hline & $50 \%$ & $33 \%$ & $17 \%$ & $50 \%$ & $31 \%$ & $19 \%$ & \\
\hline \multirow{2}{*}{$\begin{array}{l}\text { 2. The ability to analyze the effectiveness of the } \\
\text { professional communication strategies in the } \\
\text { activities of colleagues }\end{array}$} & 3 & 5 & 4 & 4 & 8 & 4 & \multirow[t]{2}{*}{0,26} \\
\hline & $25 \%$ & $42 \%$ & $33 \%$ & $25 \%$ & $50 \%$ & $25 \%$ & \\
\hline
\end{tabular}

In order to better understand the content of the tutor's activities in an open educational environment, we will indicate a number of tasks that the tutor solves:

- $\quad$ encouraging students to take their place in the educational program, that is, to introduce each student to the position of a subject of educational activity, self-learning, solving their own problems;

- $\quad$ revealing the idea of the educational program to students;

- understanding the expectations, needs, and initial level of development of students and helping them design their own trajectory in the program;

- training in effective learning activities;

- creating conditions for the integration of the educational, social, and professional environments in the educational process;

- $\quad$ creating conditions for the cooperating of the two subjects: the student and the tutor.

\section{DISCUSSION}

As we noted above, the open educational environment is characterized by diverse content, which is represented by both formal and non-formal educational programs and informal educational courses. Courses of informal education, presented on the platforms of mass online open courses, are structured so the concept of an educational program is also applicable to them.

The variability, redundancy of the open educational environment, and reliance on independent learning may seem insurmountable obstacles for the student. Therefore, one of the most important activities of the tutor is the design activity.

Goal setting is primary in design activities.

We identify several factors involved in the goal-setting process:

- the student as a direct consumer of educational services, whose problems (personal, professional, social), needs and motives serve as the main point in the formation of educational programs;

- the student as a subject of educational activities for the development of this program, a self-learner who has his own educational goals aimed at personal development and competence growth;

- the organization which the student belongs to formulates an order for the student's education based on the problems of its functioning, development and requirements for the level of competence of specialists; 
- the social environment that generates and presents to the outside a certain system of reference points and values corresponding to the cultural and historical period of the society development;

- the state that regulates the general level of education puts forward requirements in the form of an educational standard and performs an examination of the compliance of the specialists ' training with the specified level of education;

- the educational organization in the open education system that accepts the listed types of orders for education and develops educational programs that correspond to its mission and goals on this basis. The educational organization is represented in this chain by the course team, which includes the tutor. It is important to note that the educational organization, often at the point of entry receives the divergent and even conflicting goals. The aims of an open educational organization are based on the intersection of externally set goals and their own mission.

It is important to note that during the goal setting process the student plays different roles. The first role is a consumer of the service, the second role is a subject of educational activities. The goal-setting cycle begins and ends with the student, but in the process of creating an educational program, the student is transformed from a consumer, an "object" of influence into a partner, a "subject" of self-learning and self-development.

Levels of educational goals in the open educational system should also be considered:

The first level goals present students as consumers of educational services, who form an order for the open education system for goals-aspirations, goals-desires, goals-plans, and goals-values.

The second level goals include the educational organization, represented by the course team, recoding the goalsorders and their translation into the goal-program aimed at achieving educational results, real changes that occur in the student's knowledge, skills, abilities, personal qualities, value orientations, and levels of competence. Moreover, these changes are considered in the context of the development of the organization.

The third level goals include the tutor, as a representative of the team, perceiving the goals of the educational program passed to him by the course developers, performing the decoding of the "goal-program" into the "goalproject" of the training sessions. The goal-setting cycle is closed when a real student as a subject of educational activity presents the tutor with their own specific goals-tasks, goals-problems. So the process of joint goalsetting occurs and the design activity takes place.

Thus, goal-setting in the open education system is an interactive process, since one of the main points in the open education system is the constant development of educational programs.

\section{CONCLUSION}

The process of designing an educational program in an open educational environment is a multi-level system of design activities, consisting of three design cycles. Each cycle, in turn, contains a number of levels and stages of design.

The first cycle is conceptual, it represents the content and technological design of the open educational environment:

- Level "Formulation of an order for the open educational environment" possess the following characteristics: research of needs for educational services, identification of customers and consumers, coordination of the content of different orders, their integration and correlation with the possibilities of open education. At this level, there is a translation of goals-aspirations, goals-expectations, goals-plans and goalsvalues, formulated by consumers of educational services: the state, organizations, and society into the goalorder, an integrated order for the open educational environment, presented through a description of professional tasks in accordance with the required level of competence.

- Level "Conceptual and content design" includes the stages of goal setting and development of the concept of the open educational environment. At the goal setting stage, the order goals are translated into educational goals for the development of the level of competence of specialists set in the open educational environment. On the basis of educational goals, the educational process is designed in the form of interconnected cycles of students' activities (modules) that ensure the achievement of the specified levels of competence. The content-theoretical function is manifested in the fact that an adequate content of education is selected in accordance with the specified models of students' activity. The product of this level of design is the concept of the open educational environment, which includes both the educational goals of the open educational 
environment as a whole and individual modules, and the content of education selected in accordance with this concept.

- Level "Technological design" consists of a number of sequential, sometimes parallel, stages aimed at the technological design and the content of the open educational environment in accordance with accepted standards and requirements for its composition and structure. The initial stage is the further design of the training module, namely its target and activity components. The educational goals of the module are specified by designing the trajectory of achievement of these goals by students: through a sequential series of tasks, various types of students' activities are designed, the implementation of which provides the level of competence development set by the training module. In other words, there is a "marking" of the space of the training module, laying a route, a trajectory of successive achievement of the educational goals of the module by students. The product of this level of design is an integral open educational environment in its invariant part, which includes the target and activity components, which is transferred to the tutor in a particular educational institution.

The second cycle is the technical and methodological design of the open educational environment:

- Level "Design of goals (target design)" presents the tutor's reconstruction of the idea of the open educational environment, the concept and technologies incorporated in the open educational environment. Tutor at this level of design retraces the path of the designers of the open educational environment, reconstructing the first goal of the order but only in the scale of specialist's competence, then educational goals of the program and, finally, a trajectory consistent achievement of these goals, given the educational purpose of the module and tasks that reflect the types of activities students. The product of this level of the tutor's design activity is the target project presented at the level of the hierarchical scale of goals.

- Level "Modular design". studies the features, needs and potential of a specific training group, researches their capabilities and limitations, identifies conditions that contributes to the effectiveness of the educational process. On this basis the formulation of educational goals of the training module for a specific contingent of students, development of the project of training modules for the specified goals takes place.

- Level "Local design" represents the analysis of the dynamics of particular learning groups and individual learners (their level of actual development and zone of proximal development) and on this basis formulating educational goals and developing project specific training sessions. The product of this level of design is the developed projects of specific training sessions that include training goals.

- Level "Situational design" is the implementation of these functions carried out by the tutor in the course of the real educational process in direct interaction with students. The tutor with the design training sessions firstly analyzes the situation, determines the current psychological, informative willingness of the students and then diagnosing the results provides the situational design. In the design process, at a certain stage, the student is included, presenting their own educational goals that arose on the basis of real difficulties and problems in solving educational tasks. The product of the design activity of this level is a project supplemented by the activity of students, in which the goals of students are organically integrated.

It is important to emphasize that it is the presence of a level of situational design that completes the second design cycle that gives the psychological, informative, a new quality of getting a consistent result of educational activities at the level of specific interaction between the tutor and the student.

The third cycle is feedback. It is carried out by the tutor in the direct interaction with the development team in the form of Internet conferences, tutor schools, questionnaires of students, etc. The analysis of the OP design process makes it possible to determine the functions, goals and objectives of the tutor's design activity in the OP design system in an open educational environment.

\section{REFERENCES}

1. Atlas novyh professij. Available at http://atlas100.ru/catalog/

2. Maksimov V. V. Institut t'yutorstva kak obrazovatel'naya strategiya. - V sb. Rossiya v kontekste sovremennyh obrazovatel'nyh modelej: Programma i tezisy mezhdunarodnoj konferencii. 10-12 marta (Peredelkino). - Zhukovskij: MIM LINK, - 2000. 64 s, s. 60

3. Obuchenie effektivnomu menedzhmentu: Rukovodstvo dlya t'yutorov: Ucheb. posobie: Per. s angl. / Nauch. red. 3. SH. Atayan. - ZHukovskij: MIM LINK, 2001. - 373 s. 
4. Rokich, M. Priroda chelovecheskih cennostej / M. Rokich // Svobodnaya pressa. - 1973. - №5. S. 20-28.

5. Grabar' M.I., Krasnyanskaya K.A. Primenenie matematicheskoj statistiki v pedagogicheskih issledovaniyah. Neparametricheskie metody. - M.: Pedagogika, 1977. - $136 \mathrm{~s}$.

6. 13. Novikov D.A. Statisticheskie metody v pedagogicheskih issledovaniyah (tipovye sluchai). M.: Egves, 2004. $-67 \mathrm{~s}$.

7. Bol'shev L.N., Smirnov N.V. Tablicy matematicheskoj statistiki. - M.: Nauka, 1983. - 416 s.

8. Kovaleva T.M. Antropologicheskij vzglyad na sovremennuyu didaktiku: princip individualizacii i problema sub"ektivnosti // Pedagogika. 2013 № 5, s.51- 56.- 0,4 p.l.

9. Kovaleva, T.M. Realizaciya principa otkrytosti pri postroenii i primenenii obrazovatel'nyh tekhnologij /T.M. Kovaleva// Otechestvennaya i zarubezhnaya pedagogika. - 2014. - № 4., s.63-71.- 0,5 p.1. 